\title{
Renal Pelvis and Ureter Cancer Pathologic TNM Finding v7
}

National Cancer Institute

\section{Source}

National Cancer Institute. Renal Pelvis and Ureter Cancer Pathologic TNM Finding v7. NCI Thesaurus. Code C89305.

A pathologic finding about one or more characteristics of renal pelvis and ureter cancer, following the rules of the TNM AJCC v7 classification system. Pathologic staging depends on histologic determination of the extent of invasion by the primary tumor. (from AJCC 7th Ed.) 